\title{
PHF10 wt Allele
}

National Cancer Institute

\section{Source}

National Cancer Institute. PHF10 wt Allele. NCI Thesaurus. Code C157271.

Human PHF10 wild-type allele is located in the vicinity of $6 \mathrm{q} 27$ and is approximately $22 \mathrm{~kb}$ in length. This allele, which encodes PHD finger protein 10, plays a role in chromatin remodeling and neural progenitor cell maintenance. 